\title{
Levels of Trihalomethanes in Stored Water from High and Fundamental Schools: Comparison between Two Temporal Data Sets
}

\author{
Ricardo Andreola1, Anny Rosi Mannigel1, Graciene de Souza Bido', Thaise Moser Teixeira1, \\ Edison Schmidt Filho1, Jussara Ricardo de Oliveira1, André Ribeiro da Costa1, \\ Rebecca Manesco Paixão²
}

${ }^{1}$ Centro Universitário de Maringá (UNICESUMAR), Maringá, Brazil

${ }^{2}$ Universidade Estadual de Maringá (UEM), Maringá, Brazil

Email: randreola25@uol.com.br, ricardo.andreola@unicesumar.edu.br

How to cite this paper: Andreola, R., Mannigel, A.R., Bido, G. de S., Teixeira, T.M., Filho, E.S., de Oliveira, J.R., da Costa, A.R. and Paixão, R.M. (2018) Levels of Trihalomethanes in Stored Water from High and Fundamental Schools: Comparison between Two Temporal Data Sets. Journal of Water Resource and Protection, 10, 577-586.

https://doi.org/10.4236/jwarp.2018.106032

Received: February 17, 2018

Accepted: June 25, 2018

Published: June 28, 2018

Copyright (c) 2018 by authors and Scientific Research Publishing Inc. This work is licensed under the Creative Commons Attribution International License (CC BY 4.0).

http://creativecommons.org/licenses/by/4.0/

\section{(c) (i) Open Access}

\begin{abstract}
Epidemiological studies have been investigating the relationship between chlorination byproducts exposure and cancer. Studies showed the incidence of colon, rectum and bladder cancer in laboratory animals when halogenated byproducts were administered to them, such as trihalomethanes. Based on this fact, in this work, two data sets of water quality parameters were analyzed with focus on total trihalomethanes (THMt). These two data sets are from two different time periods (one in 2014 and other in 2017). All the samples were collected in the same months, in both data sets. The samples were taken from its same corresponding sampling points in both periods of time. Trihalomethanes (THMs) are undesired byproducts of chlorination and its formation occurs when the chlorine used in water treatment reacts with natural organic matter, which is present in natural waters, during the disinfection process. The aim of this research was to investigate the THMs levels in storage water from the chlorination performed by the Water Treatment Station (WTS) of the Maringá-Parana-Brazil; also, to compare the results obtained with the maximum allowable values (MAVs) established by the Consolidation Resolution n.05/2017, current law of water quality in Brazil. Water samples were collected in eight high and fundamental schools of Maringá-Paraná-Brazil and analyzed through the gas chromatography method by the use of mass spectrometry detector with purge-and-trap concentrator (GC-MS) for THM. Furthermore, parameters such as $\mathrm{pH}$ and residual chlorine were analyzed following the methodology proposed by the Standard Methods for the Examination of Water and Wastewater. The study results to THMt show that the maximum value of $21.5 \mu \mathrm{g} / \mathrm{L}$ obtained is within the MAV of $100 \mu \mathrm{g} / \mathrm{L}$. Chloroform was
\end{abstract}


the compound with higher concentrations in all samples in THMt analysis. Results of residual chlorine and $\mathrm{pH}$ also are within the MAVs. Studies like this are important to continuous monitoring of the water quality distributed to population.

\section{Keywords}

Water Treatment, Chlorination Byproducts, Cancer, Tap Water

\section{Introduction}

According to Consolidation Resolution n.05/2017 [1], current law of water quality in Brazil, which sets forth the procedures of control and surveillance of water quality for human consumption and potable water standards, the water has to pass by a disinfection process that will inactivate pathogenic microorganisms. During the process the water may receive different chemical disinfectants; however, the chlorine is the most popular in the treatment of potable water and wastewater worldwide [2] [3].

The consequences of reactions between chlorine and natural organic compounds (NOCs) are the undesired byproducts of chlorination (as trihalomethanes and haloacetic acids), which occur since the treatment beginning, when there is the pre-chlorination in the Water Treatment Station-WTS [4] [5]. The chlorination byproducts formation depends on several factors including the concentration of humic and fulvic acids, $\mathrm{pH}$, temperature, contact time, concentration of chlorine and bromides dosage [6] [7] [8]. Although several are the byproducts of chlorination, the principals are trihalomethanes, haloacetic acids, haloacetonitrile, haloketones, halonitromethanes [9] [10].

The trihalomethanes (THMs) are the most significant group of chlorination byproducts, and the total trihalomethanes (THMt) correspond to the algebraic sum of THMs most commonly found in tap water, named trichloromethane $\left(\mathrm{CHCl}_{3}\right)$, bromodichloromethane $\left(\mathrm{CHBrCl}_{2}\right)$, dibromochloromethane $\left(\mathrm{CHBr}_{2} \mathrm{Cl}\right)$, and tribromomethane $\left(\mathrm{CHBr}_{3}\right)$ [6] [11].

According to the United States Environmental Protection Agency [12] since the discovery of chlorination byproducts presence in potable water in 1974, several are the epidemiological studies that have investigated the relationship between exposure to disinfection byproducts and cancer. The International Agency for Research on Cancer (IARC) cites that THMt may cause diverse damages for human health, such as liver cancer, kidney cancer, effects on reproduction, and effects in the nervous system, according to the given classification. Trichloromethane (TCM), bromodichloromethane (BDCM) and tribromomethane (TBM) are rated $2 \mathrm{~B}$, which mean possible carcinogenic chlorination byproducts to humans, while dibromochloromethane (DBCM) has a rating $2 \mathrm{~A}$, which is a byproduct of the chlorination probably carcinogenic to humans [13]. Another study cites THMs in the incidence of colon, rectum and bladder cancer in labor- 
atory animals when halogenated byproducts were administered to them [14].

Many studies have been developed to analyze the levels, safe exposion to disinfection byproducts and the main vias of intake them. The authors [15] cite that indirect inhalation via evaporation from water, especially in bathrooms, was the major route of exposure to halogenated volatile compounds and accounted for 1.2 - 9 liter-equivalents/day for the median-exposure subpopulation. The ingestion of food was a major indirect route of exposure to haloacetic acids (HAAs). Contributions of direct water intake were the major route to trihalomethanes. In Ireland a large study in THM was conducted in country and indicated that chloroform contributed to the majority of the THMt in the drinking water supplies and the supply networks contributed to about 30 $\mu \mathrm{g} \cdot \mathrm{L}^{-1}$ of THMt [16].

The THM formation occurs in two steps. Firstly, the kinetic is favored by the presence of non-ionized form of $\mathrm{HOCl}$ at acid $\mathrm{pH}$, while in the second step, a catalytic hydrolysis occurs in basic medium, favored by higher $\mathrm{pH}$ [6].The authors [17] have already shown that the THMs reaction rate increases as the temperature increases, leading to an increased concentration of THMt as well.

Given the importance of knowing these byproducts to the quality of treated water, and the high proportion of byproducts of chlorination in water, the objective of the study was to investigate the presence of THMs in potable water distributed in High and Fundamental Schools in Maringá-Brazil. In addition, it was investigated the influence of $\mathrm{pH}$, and residual chlorine in order to compare the values found in treated water with those recommended in the Consolidation Resolution n.05/2017 [1] to $\mathrm{pH}$, residual chlorine and THMt. According to this resolution, the MAV to THMt is $100 \mu \mathrm{g} / \mathrm{L}$, minimum residual chlorine is 0.2 $\mathrm{mg} / \mathrm{L}$ and to $\mathrm{pH}$ the range of 6.0 to 9.5 .

\section{Materials and Methods}

The two studies were performed in Maringá-Brazil, latitude $23^{\circ} 25^{\prime} 31^{\prime \prime} \mathrm{S}$ and longitude $51^{\circ} 56^{\prime} 19^{\prime \prime} \mathrm{W}$, where points around the city that maximize the chlorination byproducts formation were selected for water samples. Each sampling point (eight in total) corresponds to municipal or state schools, which are located far from WTS. The WTS does not realize water analyzes for detection and quantification of chlorination byproducts levels in this points because the water is from internal reservoir. The Consolidation Resolution n.05/2017 [1] sets that sampling by WTS must be done before water entering in the house/building, in the point called "cavalete".

Two data set of water quality parameters were compared with focus on total trihalomethanes (THMt). These two data sets are from two different time periods (one in 2014 and other in 2017) separated by three years from each other. All the samples were collected in the same months, in both data sets. The samples were taken from its same corresponding sampling points in both periods of time. Figure 1 shows the location of sampling points in each school selected in the map of Maringá-Brazil. 


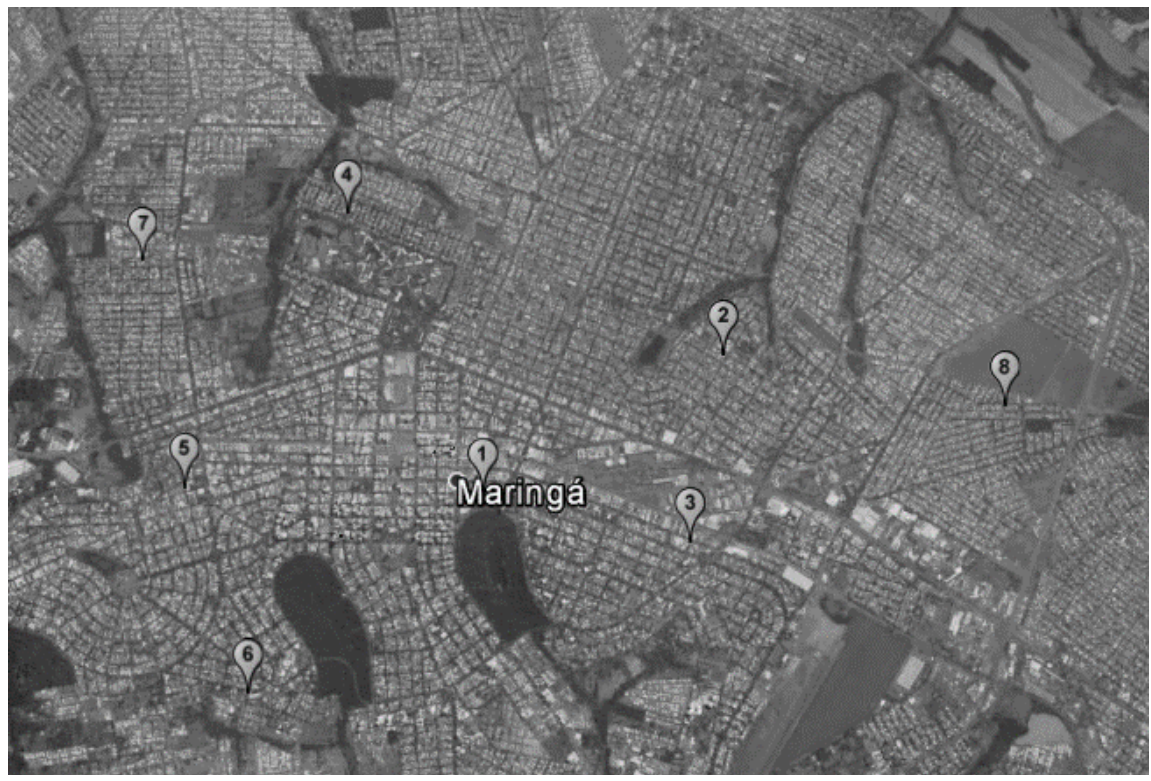

Figure 1. Location of sampling points in Maringá-Brazil. Source: Google Earth, 2018.

Three important factors were considered when choosing the sampling point: location, reservoir storage capacity and cleaning time of the reservoir. Questionnaires were used for selection of sampling points so as to maximize the load of organic matter in the reservoir. Considering the cleaning time of reservoir, when not performed at least once in a semester may lead an accumulation of organic matter, which results in a likely of high concentrations of THMs.

For each sampling point the following analysis were performed: total trihalomethanes (THMt) by gas chromatography with detection by mass spectrometry (GC-MS); residual chlorine by the DPD colorimetric method and $\mathrm{pH}$ by the potentiometric method. Analytical methods were performed following the recommendations of Standard Methods for the Examination of Water and Wastewater [18].

\section{Results and Discussion}

The $\mathrm{pH}$ values are shown in Figure 2(a) and Figure 2(b) to the first and second data set, respectively. All sampling points presented the $\mathrm{pH}$ neutral, with average value (arithmetic mean) of 7.3 to the first data set and 7.4 to the second data set. This values are close to that found by [19], in a study conducted in Canada with an average of 7.37 in same conditions. All the $\mathrm{pH}$ values from the present study are within the parameters required by the Consolidation Resolution n.05/2017 [1] which recommends that public water supply should have the $\mathrm{pH}$ maintained in the range of 6.0 to 9.5 .

As higher is the dosage of chlorine, greater is the formation of THM and free chlorine has greater capacity to form THM than combined chlorine [20] [21] [22]. Furthermore, the World Health Organization (WHO) considers that for a satisfactory disinfection, $0.5 \mathrm{mg} / \mathrm{L}$ of free residual chlorine is enough, but adverse effects are not observed in the case of concentrations of $5 \mathrm{mg} / \mathrm{L}$ [14]. 


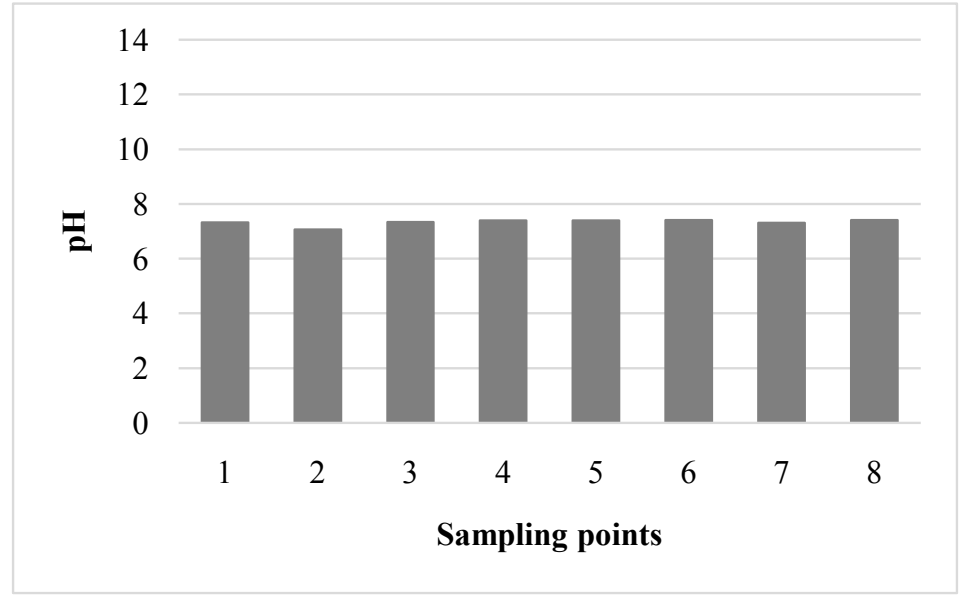

(a)

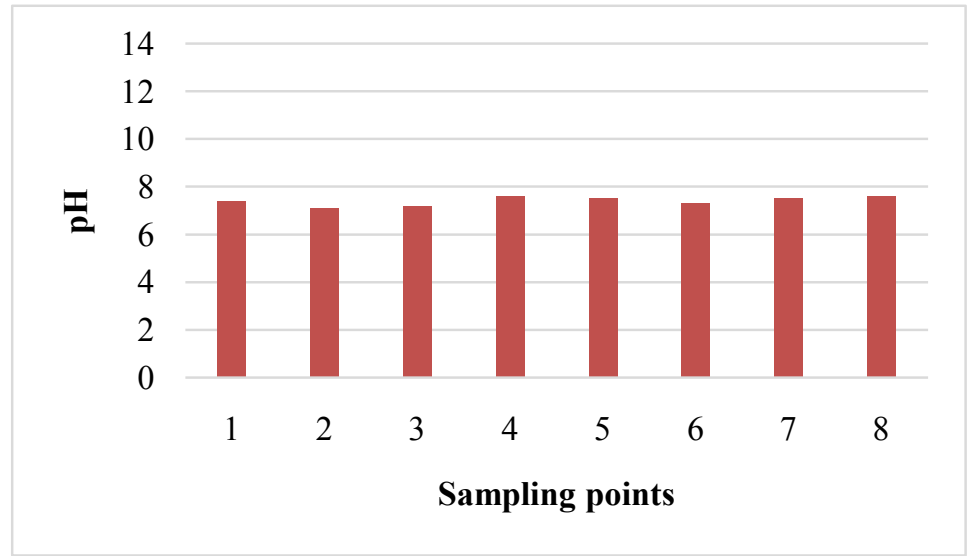

(b)

Figure 2. (a) $\mathrm{pH}$ values of treated water to the first data set; (b) $\mathrm{pH}$ values of treated water to the second data set.

The Consolidation Resolution n.05/2017 [1] considers that the residual chlorine parameter must to be maintained in values of 0.2 to $2 \mathrm{mg} / \mathrm{L}$ in distribution system, considering the network and the reservoir. Thus, the values obtained for this parameter are in accordance with current law and the average value (arithmetic mean) observed in this study was $0.38 \mathrm{mg} / \mathrm{L}$ to the first data set and 0.41 to the second data set. Figure 3(a) and Figure 3(b) show results to residual chlorine.

The THMt values correspond to the algebraic sum of four trihalomethanes concentrations analyzed: trichloromethane (TCM), bromodichloromethane (BDCM), dibromochloromethane (DBCM) and tribromomethane (TBM). The results of individuals THMs which were found in the water samples collected in the selected schools are presented in Figure 4(a) and Figure 4(b). In both data sets only TCM and BDCM was detected. All the studied city regions have same conditions in altitude and weather.

According to Figure 4(a) and Figure 4(b) the trichloromethane (TCM) (popularly known as chloroform) showed the highest concentration in all samples, 


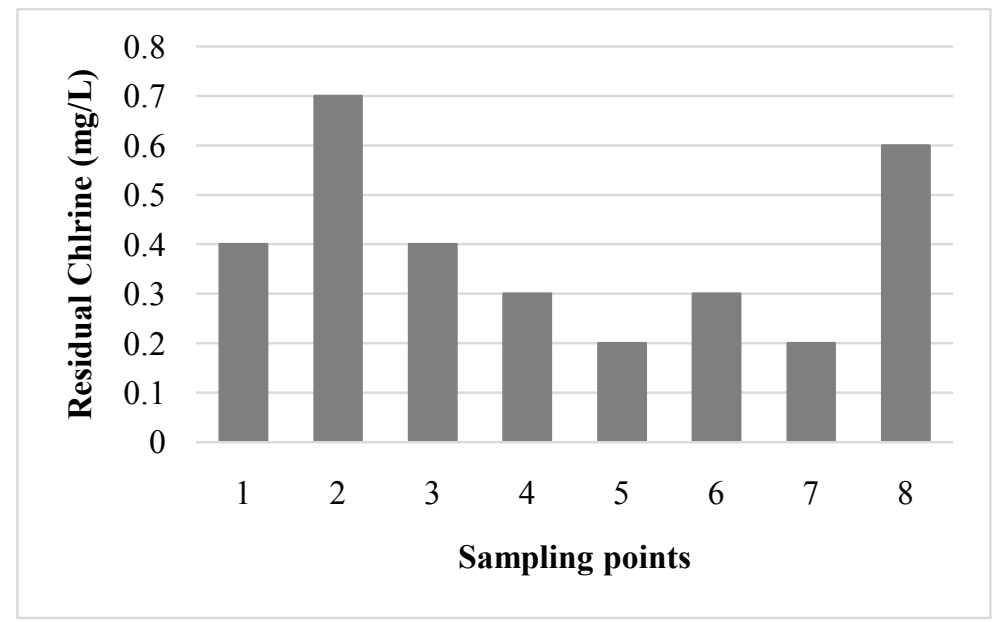

(a)

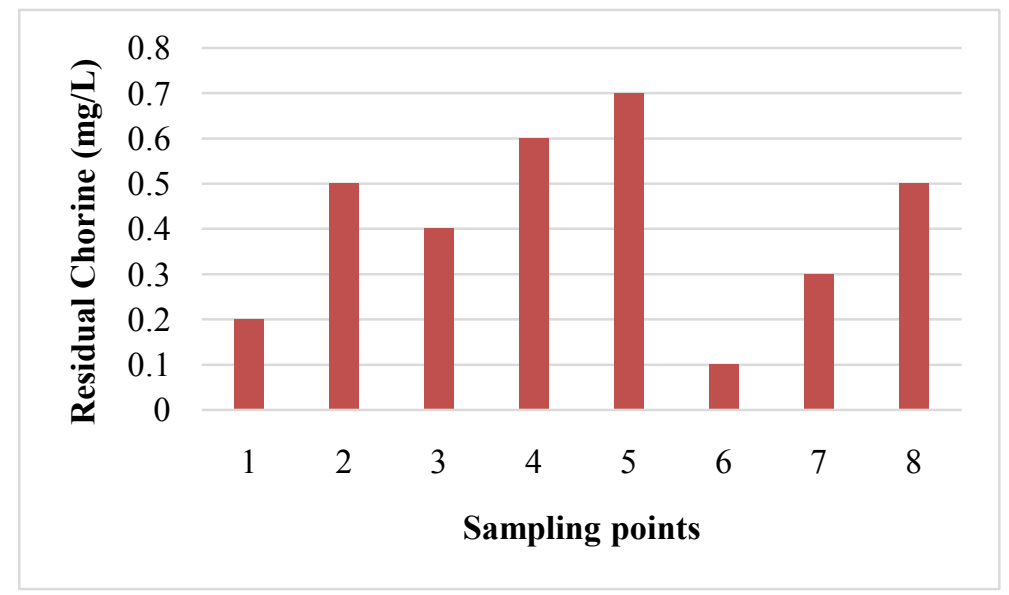

(b)

Figure 3. (a) Residual chlorine concentration in the sample points to the first data set; (b) Residual chlorine concentration in the sample points to the second data set.

with the average percentage of $75 \%$ from the THMt found in all the samples. After this byproduct, the largest contribution to the THMt was the bromodichloromethane (BDCM), with the average percentage of $25 \%$. The average values (arithmetic mean) of THMt found in all sampling points was $14.07 \mu \mathrm{g} / \mathrm{L}$ in the first data set and 18.15 to the second.

The high concentration of chloroform in the treated water can be explained by the higher residual chlorine content in the water due to the chlorination process used by the WTS and the probable low concentration of bromine in water, since the chlorine component, is more electronegative than bromine, tending to be more reactive. The author [23] states that water that shows high concentrations of bromide, the possibility of formation of larger amounts of brominated species, such as bromoform is also higher.

In a study [24], chloroform was the THM that had the highest concentrations, reaching an average percentage of $95 \%$, demonstrating the near absence of bromide ion in the treated water intended for public supply. The acceptable limit 


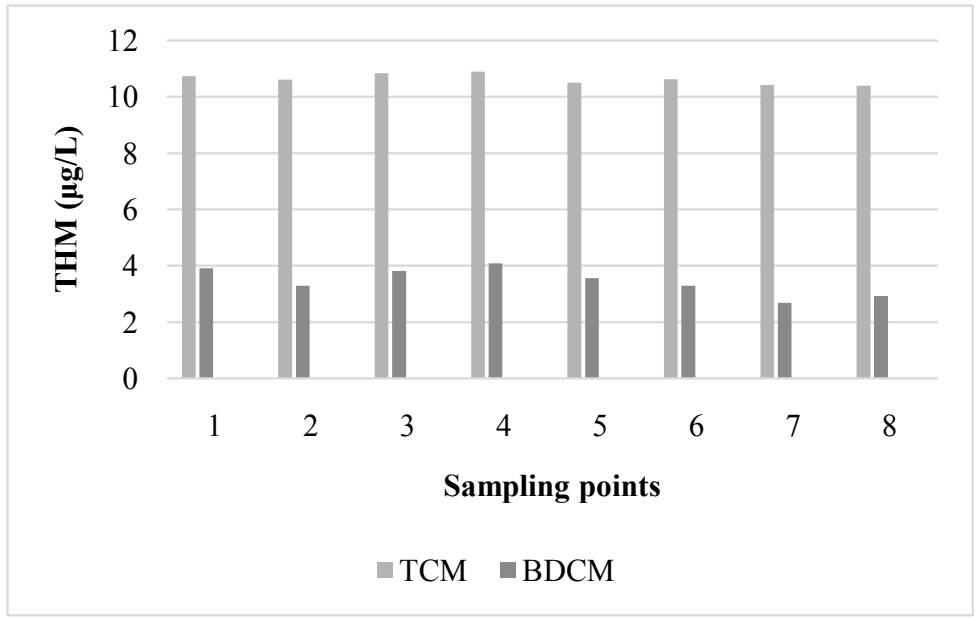

(a)

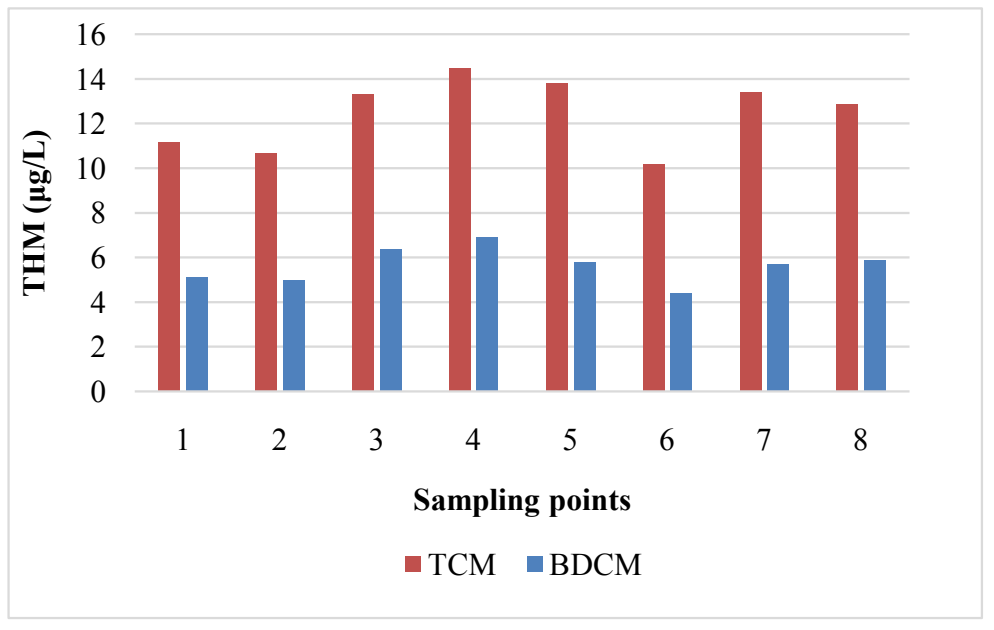

(b)

Figure 4. (a) THMs concentrations in the sample points to the first data set; (b) THMs concentrations in the sample points to the second data set.

for THMt, according to the Consolidation Resolution n.05/2017 [1] is $100 \mu \mathrm{g} / \mathrm{L}$, all the concentrations are below the specified maximum value in both data sets. It was obtained a small increase in average THMt concentration in the second data set from the first. THMs are just some of the existing chlorination byproducts and their control in drinking water can help to reduce levels of other byproducts such as haloacetic acids.

\section{Conclusions}

1) From all sampling points of this study it was found a low concentration of THMs in the treated water from the public supply. The maximum value observed was $21.4 \mu \mathrm{g} / \mathrm{L}$ in the second data set, value below the MAV $100 \mu \mathrm{g} / \mathrm{L}$ established by Consolidation Resolution n.05/2017.

2) Among the four quantified trihalomethanes, the chloroform showed the highest concentrations, representing the average percentage of $75 \%$ of THMs 
found. The results suggest a minimal presence of brominated species in the source of water.

3) The values of residual chlorine were generally low when compared with the results of studies under similar conditions. For residual chlorine, concentrations below of $0.2 \mathrm{mg} / \mathrm{L}$ were found, which are preoccupant.

4) The present study also suggests an establishment of MAVs for specific THMs in Brazil, rather than the regulation only in THMt, since THMs may have different adverse effects to human health.

\section{Acknowledgements}

The authors thank to Centro Universitário de Maringá (UNICESUMAR) for the financial and technical support.

\section{References}

[1] Brasil (2017) Portaria de Consolidação n. 05 de 28 de setembro de 2017. Consolidação das normas sobre as ações e os serviços de saúde do Sistema Único de Saúde. Diário Oficial da União, Brasília.

[2] Brown, M.A., Miller, S. and Emmer, G.L. (2007) On-Line Purge and Trap Gas Chromatography for Monitoring of Trihalomethanes in Drinking Water Distribution Systems. Analytica Chimica Acta, 592, 154-161.

https://doi.org/10.1016/j.aca.2007.04.020

[3] Telles, D.D. (2013) Ciclo Ambiental da Água: Da chuva à gestão. Edgar Blücher, São Paulo, 504 p.

[4] Andreola, R., Bergamasco, R., Gimenes, M.L., Dias Filho, B.P. and Constantino, A.F. (2005) Formação de trialometanos em uma estação de tratamento de água. $A c$ ta Scientarium Technology, 27, 133-141. https://doi.org/10.4025/actascitechnol.v27i2.1457

[5] Malliarou, E., Collins, C., Graham, N. and Nieuwenhuijsen, M.J. (2005) Haloacetic Acids in Drinking Water in the United Kingdom. Water Research, 39, 2722-2730. https://doi.org/10.1016/j.watres.2005.04.052

[6] Rodríguez, M.J., Rodríguez, G., Sérodes, J.B. and Sadiq, R. (2007) Subproductos de la desinfección del agua potable: formación, aspectos sanitarios y reglamentación. Interciencia, 32, 749-756.

[7] Nieuwenhuijsen, M.J., Martinez, D., Grellier, J., Bennet, J., Best, N., Iszatt, N., Vrijheid, M. and Toledano, M.B. (2010) Chlorination Disinfection By-Products in Drinking Water and Congenital Anomalies: Review and Meta-Analyses. Ciência \& saúde coletiva, 15, 3109-3123. https://doi.org/10.1590/S1413-81232010000800015

[8] Chowdhury, S. (2013) Trihalomethanes in Drinking Water: Effect of Natural Organic Matter Distribution. Water SA, 39, 1-7. https://doi.org/10.4314/wsa.v39i1.1

[9] Lee, S.C., Guo, H., Lam, S.M.J. and Lau, S.L.A. (2004) Multipathway Risk Assessment on Disinfection By-Products of Drinking Water in Hong Kong. Environmental Research, 94, 47-56. https://doi.org/10.1016/S0013-9351(03)00067-7

[10] Chow, A.T., Gao, S. and Dahlgren, R.A. (2005) Physical and Chemical Fractionation of Dissolved Organic Matter and Trihalomethane Precursors: A Review. Journal of Water Supply Research Technology-Aqua, 54, 475-507. https://doi.org/10.2166/aqua.2005.0044 
[11] Viana, R.B., Cavalcante, R.M., Braga, F.M.G., Viana, A.B., Araujo, J.C., Nascimento, R.F. and Pimentel, A.S. (2008) Risk Assessment of Trihalomethanes from Tap Water in Fortaleza. Environmental Monitoring and Assessment, 151, 317-325. https://doi.org/10.1007/s10661-008-0273-y

[12] USEPA (2008) Disinfection Byproduct Health Effects.US Environmental Protection Agency. http://www.epa.gov

[13] IARC-International Agency for Research on Cancer (2009) Overall Evaluations of Carcinogenicity to Humans-List of All Agents, Mixtures and Exposures Evaluated to Date. WHO, Geneva. http://monographs.iarc.fr

[14] Tominaga, M. and Midio, A.F. (1999) Exposição humana a trialometanos presentes em água tratada. Revista de Saúde Pública, 33, 413-421.

https://doi.org/10.1590/S0034-89101999000400013

[15] Akiyama, M., Matsui, Y., Kido, J., Matsushita, T. and Shirasaki, N. (2018) Monte-Carlo and Multi-Exposure Assessment for the Derivation of Criteria for Disinfection Byproducts and Volatile Organic Compounds in drinking Water: Allocation Factors and Liter-Equivalents per Day. Regulatory Toxicology and Pharmacology, 95, 161-174. https://doi.org/10.1016/j.yrtph.2018.03.009

[16] O'driscoll, C., Sheahan, J., Renou-Wilson, F., Croot, P., Pilla, F., Misstear, B. and Xiao, L. (2018) National Scale Assessment of Total Trihalomethanes in Irish Drinking Water. Journal of Environmental Management, 212, 131-141. https://doi.org/10.1016/j.jenvman.2018.01.070

[17] Chowdhury, S., Champagne, P. and Mclellan, P.J. (2010) Investigating Effects of Bromide Ions on Trihalomethanes and Developing Model for Predicting Bromodichloromethane in Drinking Water. Water Research, 44, 2349-2359. https://doi.org/10.1016/j.watres.2009.12.042

[18] APHA, AWWA, WEF (1998) Standard Methods for the Examination of Water and Wastewater. 20th Edition, APHA, Washington DC.

[19] Dion-Fortier, A., Rodriguez, M.J., Sérodes, J. and Proulx, F. (2009) Impact of Water Stagnation in Residential Cold and Hot Water Plumbing on Concentrations of Trihalomethanes and Haloacetic Acids. Water Research, 43, 3057-3066. https://doi.org/10.1016/j.watres.2009.04.019

[20] Meyer, S.T. (1994) O Uso de Cloro na Desinfecção de Águas, a Formação de Trihalometanos e os riscos Potenciais à Saúde Pública. Cadernos de Saúde Pública, 1, 99-110. https://doi.org/10.1590/S0102-311X1994000100011

[21] Pádua, V.L., Azevedo, S.M.F.O., Ferreira, A.C.S., Vieira, F.M.A.C., Avelino, F.F., Braga, F.M.G., Lemos, L., Sales, M.V., Andrade, M.I.R., Jimenez, P.C., Araújo, J.C., Freire, R.E. and Amorim, R.N. (2007) Potenciais fatores de risco à saúde decorrentes da presença de subprodutos de cloração na água utilizada para consumo humano. Funasa, Brasília, 127 p.

[22] Ye, T., Xu, B., Wang, Z., Zhang, T.-Y., Hu, C.-Y., Lin, L., Xia, S.-J. and Gao, N.-Y. (2014) Comparison of Iodinated Trihalomethanes Formation during Aqueous Chlor(am)ination of Different Iodinated X-Ray Contrast Media Compounds in the Presence of Natural Organic Matter. Water Research, 66, 390-398.

https://doi.org/10.1016/j.watres.2014.08.044

[23] Singer, P.C. (1994) Control of Disinfection By-Products in Drinking Water. Journal of Environmental Engineering, 120, 727-744. https://doi.org/10.1061/(ASCE)0733-9372(1994)120:4(727)

[24] Paschoalato, C.F.P.R., Trimailovas, M.R. and Di Bernardo, L. (2008) Formação de subprodutos orgânicos halogenados nas operações de pré-oxidação com cloro, 
ozônio e peroxônio e pós cloração em água contendo substância húmica. Engenharia Sanitária e Ambiental, 13, 313-322.

https://doi.org/10.1590/S1413-41522008000300011 